\title{
PENGARUH DIVIDEN PAYOUT RATIO, PRICE TO BOOK VALUE RATIO, DAN PRICE TO EARNING RATIO TERHADAP RETURN SAHAM PADA PERUSAHAAN ASURANSI YANG TERDAFTAR DI BEI
}

\author{
Hanik Mariana ${ }^{1}$ \\ Miladiah Kusumaningarti ${ }^{2}$ \\ ${ }^{1}$ Prodi Akuntansi Fakultas Ekonomi Universitas Islam Kadiri Kediri \\ ${ }^{2}$ Prodi Akuntansi Fakultas Ekonomi Universitas Islam Kadiri Kediri
}

\begin{abstract}
Abstrak
Penelitian ini bertujuan untuk mengetahui pengaruh dividen payout ratio, price to book value ratio, dan price to earning ratio terhadap return saham pada perusahaan asuransi yang terdaftar di BEI periode 2015-2017. Variabel independen yang digunakan dalam penelitian ini adalah dividen payout ratio, price to book value ratio, dan price to earning ratio. Variabel dependen yang digunakan dalam penelitian ini adalah return saham. Penelitian ini menggunakan data sekunder dengan jumlah sampel 7 perusahaan. Analisis data digunakan dengan regresi linier berganda dengan bantuan SPSS'16 dan juga menggunakan teknik purposive sampling.

Hasil penelitian menunjukkan bahwa secara parsial dividen payout ratio berpengaruh terhadap return saham, price to book value ratio tidak berpengaruh terhadap return saham dan price to earning ratio tidak berpengaruh terhadap return saham. Secara simultan dividen payout ratio, price to book value ratio, dan price to earning ratio tidak berpengaruh terhadap return saham.

Kemampuan prediksi dari ketiga variabel terhadap return saham diperoleh $\mathrm{R}$ Square sebesar 0,239 atau 23,90\% dapat disimpulkan bahwa variabel dividen payout ratio, price to book value ratio, dan price to earning ratio mampu mempengaruhi return saham sebesar $23,90 \%$ dan sisanya $76,10 \%$ dipengaruhi oleh variabel lain diluar penelitian.
\end{abstract}

Kata Kunci : dividen payout ratio, price to book value ratio, price to earning ratio, dan return saham. 


\begin{abstract}
This study aims to determine the effect of dividend payout ratio, price to book value ratio, and price to earnings ratio on stock returns in insurance companies listed on the Indonesia Stock Exchange for the period 2015-2017. The independent variable used in this study is dividend payout ratio, price to book value ratio, and price to earnings ratio. The dependent variable used in this study is stock returns. This study uses secondary data with a sample of 7 companies. Data analysis was used with multiple linear regression with the help of SPSS 16 and also using purposive sampling technique.

The results show that partially dividend payout ratio has an effect on stock returns, price to book value ratio does not affect stock returns and price to earnings ratio does not affect stock returns. Simultaneously dividend payout ratio, price to book value ratio, and price to earnings ratio do not affect stock returns. Predictive ability of the three variables on stock returns obtained by $R$ Square of 0.239 or $23.90 \%$ can be concluded that the variable dividend payout ratio, price to book value ratio, and price to earnings ratio can influence stock returns of $23.90 \%$ and the remaining $76,10 \%$ is influenced by other variables outside the research.
\end{abstract}

Keywords : dividend payout ratio, price to book value ratio, price to earnings ratio, and stock return.

\title{
I. PENDAHULUAN
}

Pada dasarnya dana yang dimiliki setiap orang dapat ditanamkan ke dalam berbagai investasi, seperti investasi pada proyek, investasi pada perdagangan valuta asing, obligasi maupun investasi saham. Dalam menginvestasikan sejumlah dana seorang investor mengharapkan mendapat keuntungan yang diperoleh di masa yang akan datang. Untuk itu investor perlu melakukan analisis untuk menentukan dasar yang dapat digunakan dalam menilai kelayakan saham untuk dijadikan sebagai salah satu alternatif investasi. Semakin berkembangnya perekonomian di dunia mengakibatkan perubahan yang signifikan di berbagai bidang kehidupan. Orang mulai melakukan transaksi ekonomi melalui berbagai cara, salah satunya adalah dengan menginvestasikan harta atau uangnya melalui pasar modal. Kehidupan yang semakin kompleks akan mendorong berbagai pihak untuk mendapatkan segala sesuatu secara instan, mudah, dan terorganisasi.

Return saham merupakan hasil yang diperoleh dari kegiatan investasi. Harapan untuk memperoleh return yang maksimal tersebut diusahakan agar dapat terwujud dengan mengadakan analisis dan upaya tindakan-tindakan yang berkaitan dengan investasi dalam sahamnya. Oleh karena itu, perlu diketahui faktor-faktor yang mempengaruhi return saham sehingga harapan untuk memperoleh return yang maksimal bisa tercapai. Investor maupun calon investor saham mengunakan rasio pasar sebagai pedoman dalam pengambilan keputusan sebelum memilih saham yang akan dibeli. Rasio pasar terdiri dari Dividen Payout Ratio (DPR), Price to Book Value Ratio (PBV), dan Price to Earning Ratio (PER). Ketiga rasio yang telah disebutkan di atas menjadi perhatian para pemegang saham dan calon pemegang saham. Dengan demikian, investor maupun calon investor saham yang merencanakan keputusan investasi pasti memperoleh 
return yang lebih tinggi dibandingkan dengan investor yang telah merencanakan keputusan investasi.

Dividen Payout Ratio (DPR) mencerminkan kebijakan perusahaan mengenai besarnya dividen yang dibagikan. Kebijakan dividen perusahaan sangat mempengaruhi kepercayaan investor yang mengharapkan return. Perusahaan yang menginginkan para investor tetap berinvestasi di dalam perusahaannya, maka perusahaan harus dapat memberikan kesejahteraan pada investornya dengan membagikan dividen setiap tahunnya. Laba perusahaan merupakan unsur dasar kebijakan dividen yang ditentukan dengan dividen payout ratio. Laba sangat penting bagi perusahaan maupun bagi investor.

Price to Book Value Ratio (PBV) merupakan perbandingan antara harga saham dengan nilai buku ekuitas perusahaan yang menunjukkan tingkat kemampuan perusahaan menciptakan nilai relatif terhadap jumlah modal yang diinvestasikan oleh pihak investor. Hal ini dikarenakan rasio PBV dapat menunjukkan seberapa jauh perusahaan mampu menciptakan nilai perusahaan relatif terhadap jumlah modal yang diinvestasikan. Meningkatnya penilaian investor terhadap suatu perusahaan tersebut akan berdampak positif terhadap return saham.

Price to Earning Ratio (PER) adalah perbandingan antara harga saham suatu emiten dengan pendapatan per saham. Rasio ini menunjukkan berapa besar investor menilai harga saham terhadap kelipatan dari earning. Apabila return saham lebih tinggi dari return pasar, maka saham tersebut layak dibeli begitu juga sebaliknya. Price to earning ratio mempunyai pengaruh yang signifikan terhadap return saham, sehingga kebanyakan dari investor memandang harga saham menjadi pertimbangan bagi investor di dalam membeli saham. Jika harga saham suatu saham perusahaan tinggi maka para investor beranggapan bahwa kinerja dari perusahaan tersebut bagus.

Berdasarkan dengan adanya ketidakkonsistenan terhadap faktor-faktor yang mempengaruhi return saham perusahaan, khususnya perusahaan asuransi yang terdaftar di Bursa Efek Indonesia, maka peneliti tertarik untuk meneliti tentang Pengaruh Dividen Payout Ratio, Price to Book Value Ratio, dan Price to Earning Ratio terhadap Return Saham pada Perusahaan Asuransi yang Terdaftar di Bursa Efek Indonesia.

\section{KAJIAN TEORI}

\section{Dividen Payout Ratio}

Dividen Payout Ratio (DPR) adalah laba yang dibayarkan dalam bentuk dividen atau dengan kata lain persentase laba yang tersedia bagi pemegang saham. Jika tingkat earning per share atau keuntungan per lembar yang diperoleh perusahaan tinggi, maka informasi ini dapat dijadikan suatu sinyal positif bagi pemegang saham karena memungkinkan perusahaan memberikan dividen lebih tinggi dari prediksi investor atau pemegang saham. Dengan demikian, dapat diinterpretasikan bahwa semakin tinggi nilai earning per share perusahaan maka semakin tinggi pula dividen payout ratio. Hal tersebut menentukan dividen yang dibagikan kepada pemegang saham mengalami peningkatan, Sutrisno (2008:267).

Prastowo (2011:94), pembayaran dividen merupakan rasio yang mengukur perbandingan dividen terhadap laba perusahaan. Seorang investor akan memperhatikan kepemilikan atas saham suatu perusahaan. Apabila mereka 
mengantisipasi bahwa saham tersebut mampu memberikan kembalian (return) yang lebih baik dibandingkan saham perusahaan lain. Return yang akan mereka terima tidak hanya berupa dividen, melainkan dapat berbentuk capital gain. Banyak investor lebih suka tidak menerima dividen melainkan berharap perusahaan menambah laba yang diperolehnya dan menginvestasikan kembali untuk memperoleh return yang lebih besar dalam bentuk capital gain.

\section{Price to Book Value Ratio}

Menurut Tryfino (2009:9), Price to Book Value Ratio (PBV) adalah perhitungan atau perbandingan antara market value dengan book value suatu saham. rasio ini berfungsi untuk melengkapi analisis book value, jika pada analisis book value investor hanya mengetahui kapasitas per lembar dari nilai saham, pada rasio $\mathrm{PBV}$ investor dapat mengetahui langsung sudah berapa kali market value suatu saham dihargai dari book value-nya.

Menurut Brigham dan Houston (2009:11), Price to Book Value Ratio (PBV) adalah rasio atas harga pasar saham terdapat nilai bukunya juga akan memberikan indikasi yang lain tentang bagaimana investor memandang perusahaan. Perusahaan dengan tingkat pengembalian ekuitas yang relatif tinggi biasanya menjual dengan perkalian rasio nilai buku yang lebih besar jika dibandingkan dengan perusahaan yang pengembaliannya rendah.

Price to Book Value Ratio (PBV) ditunjukkan dalam perbandingan antara harga saham dan nilai buku serta digunakan untuk melihat kawajaran harga saham. Hal ini berarti harga saham itu berpotensi lebih besar untuk naik, sehingga return yang diterima akan meningkat. Price to book value ratio adalah suatu nilai yang digunakan untuk membandingkan apakah sebuah saham relatif lebih mahal atau lebih murah bila dibandingkan dengan saham lainnya.

\section{Price to Earning Ratio}

Menurut Fahmi (2015:84), bagi para investor semakin tinggi Price to Earning Ratio (PER) maka pertumbuhan laba yang diharapkan juga akan mengalami kenaikan.dengan begitu price to earning ratio (rasio harga terhadap laba) adalah pembagian antara market price per share (harga pasar per lembar saham) dengan earning per share (laba per lembar saham). price to earning ratio adalah rasio yang digunakan untuk menghitung tingkat pengembalian modal yang diinvestasikan pada suatu saham, atau menghitung kemampuan suatu saham dalam menghasilkan laba. Tujuan dalam metode ini adalah untuk memprediksi kapan atau berapa kali laba yang dihasilkan perusahaan dibandingkan dengan harga sahamnya pada periode tertentu.

\section{Return Saham}

Return saham adalah hasil keuntungan (capital gain) atau kerugian (capital loss) yang diperoleh dari hasil investasi atau trading saham dalam kurun waktu tertentu. Return saham positif disebut juga capital gain sedangkan return saham negatif disebut dengan capital loss.Menurut Fahmi (2015:166), return adalah keuntungan yang diperoleh oleh perusahaan, individu dan institusi dari hasil kebijakan investasi dilakukan. Dalam berinvestasi seorang investor mengharapkan expected return. Expected return sendiri merupakan keuntungan yang diharapkan oleh seorang investor di kemudian hari terhadap sejumlah dana yang ditetapkan. 
Menurut Hartono (2009:243), return realisasi portofolio (portfolio realized return) merupakan rata-rata tertimbang dari return-return realisasi masing-masing sekuritas tunggal di dalam portofolio tersebut sedangkan return ekspektasi portofolio (portfolio expected return) merupakan rata-rata tertimbang dari returnreturn ekspektasi masing-masing sekuritas tunggal di dalam portofolio.

\section{METODE PENELITIAN}

\section{Ruang Lingkup Penelitian}

Jenis penelitian yang akan dilakukan oleh peneliti adalah studi empiris, yaitu studi yang dilakukan berdasarkan data hasil pengamatan dan bukan secara teoristis dan spekulasi yang digunakan untuk penelitian. Studi empiris terhadap perusahaan asuransi yang sahamnya terdaftar di Bursa Efek Indonesia tahun 20152017. Dalam penelitian ini yang menjadi populasi adalah perusahaan asuransi yang terdaftar di Bursa Efek Indonesia periode 2015-2017 yang berjumlah 14 perusahaan. Teknik pengambilan sampel yang digunakan adalah purposive sampling dengan beberapa kriteria yang ditentukan menghasilkan jumlah sampel sebanyak 7 perusahaan dalam periode penelitian 2015-2017.

\section{Definisi Operasional Variabel}

a. Dividen Payaout Ratio (DPR)

Rasio pembayaran dividen (dividen payout ratio) adalah menentukan jumlah laba yang dapat ditahan dalam perusahaan sebagai sumber pendanaan dan prosentase laba yang dibayarkan dalam bentuk dividen atau rasio antara laba yang dibayarkan dalam bentuk deviden dengan total laba yang tersedia bagi pemegang saham. Rumus untuk menghitung DPR adalah :

$$
D P R=\frac{\text { Dividen } \text { per share }}{\text { Earning per share }} \times 100 \%
$$

b. Price to Book Value Ratio (PBV)

Price to Book Value Ratio (PBV) adalah suatu nilai yang digunakan untuk membandingkan apakah sebuah saham relatif lebih mahal atau lebih murah bila dibandingkan dengan saham lainnya. Rumus untuk menghitung Price to PBV adalah :

$$
P B V=\frac{\text { Harga saham }}{\text { Nilai buku per lembar }}
$$

c. Price to Earning Ratio (PER)

Price to Earning Ratio (PER) adalah rasio yang digunakan untuk menghitung tingkat pengembalian modal yang diinvestasikan pada suatu saham, atau menghitung kemampuan suatu saham dalam menghasilkan laba. rumus untuk menghitung Price to Earning Ratio PER adalah : 
Jurnal Cendekia Akuntansi Vol. 1 No. 1

$$
P E R=\frac{\text { Harga saham }}{\text { Laba per lembar }}
$$

d. Return Saham

Return Saham adalah hasil keuntungan (capital gain) atau kerugian (capital loss) yang diperoleh dari hasil investasi atau trading saham dalam kurun waktu tertentu. Rumus untuk menghitung Return Saham adalah :

$$
\text { Return Saham }=\frac{P t-P t^{-1}}{P t^{-1}}
$$

\section{Teknik Analisis}

Metode analisis data yang digunakan untuk menguji hipotesis adalah metode regresi linier berganda. Dalam penelitian ini, regresi linier berganda digunakan untuk mengetahui adanya hubungan antara variabel dependen yaitu return saham dengan variabel-variabel independen yaitu Dividen Payout Ratio (DPR), Price to Book Value Ratio (PBV), dan Price to Earning Ratio (PER).

\section{HASIL PENELITIAN DAN PEMBAHASAN}

1. Perhitungan Dividen Payout Ratio

Hasil Perhitungan Dividen Payout Ratio 2015-2017

(dalam persentase (\%))

\begin{tabular}{|c|c|c|c|c|}
\hline \multirow{2}{*}{ No } & \multirow{2}{*}{ Kode Perusahaan } & \multicolumn{3}{|c|}{ DPR } \\
\cline { 3 - 5 } & & 2015 & 2016 & 2017 \\
\hline 1 & ABDA & 19,65 & 46,52 & 34,74 \\
\hline 2 & ASBI & 12,35 & 28,45 & 32,23 \\
\hline 3 & ASDM & 28,19 & 33,43 & 32,89 \\
\hline 4 & ASJT & 29,54 & 26,30 & 31,36 \\
\hline 5 & ASRM & 28,54 & 32,28 & 34,00 \\
\hline 6 & LPGI & 34,75 & 29,76 & 27,74 \\
\hline 7 & MREI & 11,36 & 12,40 & 13,21 \\
\hline
\end{tabular}

Sumber : Data diolah peneliti 2019

Berdasarkan tabel 4.1 dapat diketahui bahwa nilai dividen payout ratio tertinggi pada tahun 2015 yaitu Lippon General Insurance Tbk. dengan nilai sebesar 34,75\% dan data terendah terdapat pada Maskapai Reasuransi Indonesia Tbk. dengan nilai sebesar 11,36\%. Data dividen payout ratio tertinggi pada tahun 2016 yaitu Asuransi Bina Dana Arta Tbk. dengan nilai sebesar 46,52\% dan data terendah yaitu Maskapai Reasuransi Indonesia Tbk. dengan nilai 12,40\%. Data dividen payout ratio tertinggi pada tahun 2017 yaitu Asuransi Bina Dana Arta Tbk. dengan nilai 34,74\% dan data terendah yaitu Maskapai Reasuransi Indonesia Tbk. dengan nilai 13,21\%. 
Jurnal Cendekia ARuntansi Vol. I No. 1

\section{Hasil Perhitungan Price to Book Value Ratio 2015-2017}

\begin{tabular}{|c|c|c|c|c|}
\hline \multirow{2}{*}{ NO } & \multirow{2}{*}{ Kode Perusahaan } & 2015 & 2016 & 2017 \\
\cline { 3 - 5 } & & 4,05 & 3,48 & 3,27 \\
\hline 1 & ABDA & 0,95 & 0,76 & 0,37 \\
\hline 2 & ASBI & 0,89 & 0,69 & 0,66 \\
\hline 3 & ASDM & 0,57 & 0,61 & 1,70 \\
\hline 4 & ASJT & 1,80 & 1,86 & 1,37 \\
\hline 5 & ASRM & 0,62 & 0,68 & 0,68 \\
\hline 6 & LPGI & 3,86 & 2,21 & 1,53 \\
\hline 7 & MREI & & & \\
\hline
\end{tabular}

Sumber : Data diolah peneliti 2019

Berdasarkan tabel 4.2 dapat diketahui bahwa nilai price to book value ratio tertinggi pada tahun 2015 yaitu Asuransi Bina Dana Arta Tbk. dengan nilai sebesar Rp 4,05 dan data terendah terdapat pada Asuransi Jasa Tania Tbk. dengan nilai sebesar Rp 0,57. Data price to book value ratio tertinggi pada tahun 2016 yaitu Asuransi Bina Dana Arta Tbk. dengan nilai sebesar Rp 3,48 dan data terendah yaitu Asuransi Jasa Tania Tbk. dengan nilai Rp 0,61. Data price to book value ratio tertinggi pada tahun 2017 yaitu Asuransi Bina Dana Arta Tbk. dengan nilai sebesar Rp 3,27 dan data terendah yaitu Asuransi Bintang Tbk. dengan nilai $\operatorname{Rp} 0,37$.

\section{Hasil Perhitungan Price to Earning Ratio} 2015-2017

(dalam rupiah)

\begin{tabular}{|c|c|c|c|c|}
\hline \multirow{2}{*}{ NO } & \multirow{2}{*}{ Kode Perusahaan } & \multicolumn{3}{|c|}{ PER } \\
\cline { 3 - 5 } & & 2015 & 2016 & 2017 \\
\hline 1 & ABDA & 18,43 & 24,69 & 27,99 \\
\hline 2 & ASBI & 5,44 & 8,65 & 7,37 \\
\hline 3 & ASDM & 4,97 & 4,84 & 4,48 \\
\hline 4 & ASJT & 5,29 & 4,71 & 15,88 \\
\hline 5 & ASRM & 7,72 & 9,14 & 8,03 \\
\hline 6 & LPGI & 10,14 & 9,74 & 7,95 \\
\hline 7 & MREI & 17,77 & 11,32 & 12,86 \\
\hline
\end{tabular}

Sumber : Data diolah peneliti 2019

Berdasarkan tabel 4.3 dapat diketahui bahwa nilai price to earning ratio tertinggi pada tahun 2015 yaitu Asuransi Bina Dana Arta Tbk. dengan nilai sebesar Rp 18,43 dan data terendah terdapat pada Asuransi Dayin Mitra Tbk. dengan nilai sebesar 4,97. Data price to earning ratio tertinggi pada tahun 2016 yaitu Asuransi Bina Dana Arta Tbk. dengan nilai sebesar Rp 24,69 dan data terendah yaitu Asuransi Jasa Tania Tbk. dengan nilai Rp 4,71. Data price to 
Jurnal Cendekia Akuntansi Vol. 1 No. 1

earning ratio tertinggi pada tahun 2017 yaitu Asuransi Bina Dana Arta Tbk. dengan nilai sebesar Rp 27,99 dan data terendah yaitu Asuransi Dayin Mitra Tbk. dengan nilai $\operatorname{Rp} 4,48$.

\section{Hasil Perhitungan Return Saham 2015-2017}

\begin{tabular}{|c|c|c|c|c|}
\hline \multirow{2}{*}{ NO } & \multirow{2}{*}{ Kode Perusahaan } & \multicolumn{3}{|c|}{ Return Saham } \\
\cline { 3 - 5 } & & 2015 & 2016 & 2017 \\
\hline 1 & ABDA & 0,28 & $-0,13$ & 0,05 \\
\hline 2 & ASBI & $-0,54$ & $-0,14$ & $-0,25$ \\
\hline 3 & ASDM & 0,00 & $-0,14$ & 0,03 \\
\hline 4 & ASJT & $-0,47$ & 0,18 & 2,23 \\
\hline 5 & ASRM & 0,79 & 0,17 & $-0,15$ \\
\hline 6 & LPGI & 0,09 & 0,03 & $-0,10$ \\
\hline 7 & MREI & 0,46 & $-0,31$ & $-0,06$ \\
\hline
\end{tabular}

Sumber : Data diolah peneliti 2019

Berdasarkan tabel 4.4 dapat diketahui bahwa nilai return saham tertinggi pada tahun 2015 yaitu Asuransi Ramayana Tbk. dengan nilai sebesar Rp 0,79 dan data terendah terdapat pada Asuransi Bintang Tbk. dengan nilai sebesar Rp -0,54. Data return saham tertinggi pada tahun 2016 yaitu Asuransi Jasa Tania Tbk. dengan nilai sebesar $\mathrm{Rp} 0,18$ dan data terendah yaitu Maskapai Reasuransi Indonesia Tbk. dengan nilai Rp -0,31. Data return saham tertinggi pada tahun 2017 yaitu Asuransi Jasa Tania Tbk. dengan nilai sebesar Rp 2,23 dan data terendah yaitu Asuransi Bintang Tbk. dengan nilai Rp -0,25.

\section{Hasil Analisis Regresi Linier Berganda}

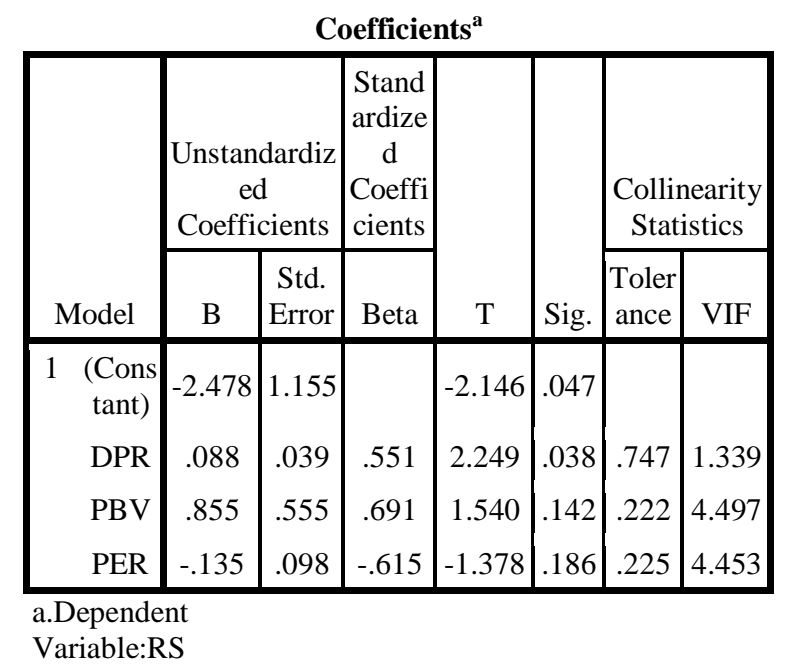

$$
\begin{gathered}
\mathrm{Y}=-2,478+0,088 \text { DPR }+0,855 \\
\text { PBV }-0,135 \text { PER }
\end{gathered}
$$


a. Pengujian Hipotesis 1

$\mathrm{H}_{0}: b_{1}=0$ Dividen payout ratio tidak berpengaruh secara parsial terhadap return saham.

$\mathrm{H}_{\mathrm{a}}: b_{1} \neq 0$ Dividen payout ratio berpengaruh secara parsial terhadap return saham.

Berdasarkan hasil perhitungan pada SPSS diperoleh nilai signifikan variabel dividen payout ratio (DPR) adalah 0,038 . Hal ini menunjukkan bahwa nilai signifikan uji t variabel dividen payout ratio (DPR) $\leq 0,05$ yang berarti $\mathrm{H}_{0}$ ditolak dan $\mathrm{H}_{\mathrm{a}}$ diterima. Hasil dari pengujian parsial ini adalah dividen payout ratio (DPR) berpengaruh signifikan terhadap return saham.

b. Pengujian Hipotesis 2

$\mathrm{H}_{0}: b_{2}=0$ Price to book value ratio tidak berpengaruh secara parsial terhadap return saham.

$\mathrm{H}_{\mathrm{a}}: b_{2} \neq 0$ Price to book value ratio berpengaruh secara parsial terhadap return saham.

Berdasarkan hasil perhitungan pada SPSS diperoleh nilai signifikan variabel price to book value ratio (PBV) adalah 0,142 . Hal ini menunjukkan bahwa nilai signifikan uji t variabel price to book value ratio $(\mathrm{PBV})>0,05$ yang berarti $\mathrm{H}_{0}$ diterima dan $\mathrm{H}_{\mathrm{a}}$ ditolak. Hasil dari pengujian parsial ini adalah price to book value ratio (PBV) tidak berpengaruh signifikan terhadap return saham.

c. Pengujian Hipotesis 3

$\mathrm{H}_{0}: b_{3}=0$ Price to earning ratio tidak berpengaruh secara parsial terhadap return saham.

$\mathrm{H}_{\mathrm{a}}: b_{3} \neq 0$ Price to earning ratio berpengaruh secara parsial terhadap return saham.

Berdasarkan hasil perhitungan pada SPSS diperoleh nilai signifikan variabel price to earning ratio (PER) adalah 0,182 . Hal ini menunjukkan bahwa nilai signifikan uji t variabel price to earning ratio (PER) $>0,05$ yang berarti $\mathrm{H}_{0}$ diterima dan $\mathrm{H}_{\mathrm{a}}$ ditolak. Hasil dari pengujian parsial ini adalah price to earning ratio (PER) tidak berpengaruh signifikan terhadap return saham.

\section{Uji Kofisien Determinasi}

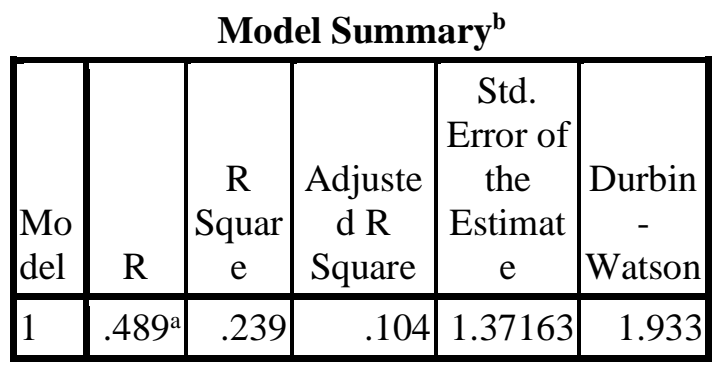

a. Predictors: (Constant), PER, DPR, PBV

b. Dependent Variable: RS

Besarnya pengaruh dividen payout ratio, price to book value ratio, dan price to earning ratio terhadap return saham dapat diketahui dari nilai koefisien determinasi simultan $\left(\mathrm{R}^{2}\right)$. Berdasarkan hasil analisis diperoleh nilai adjusted $R^{2}$ sebesar 0,104. Dengan demikian menunjukkan dividen payout ratio, price to book value ratio, dan price to earning ratio secara bersama-sama mempengaruhi return 
Jurnal Cendekia ARuntansi Vol. 1 NNo. 1

saham sebesar $10.40 \%$ dan sisanya yaitu $89,60 \%$ dipengaruhi oleh faktor lain yang tidak dikaji dalam penelitian ini.

\section{Pengujian hipotesis secara simultan (uji F)}

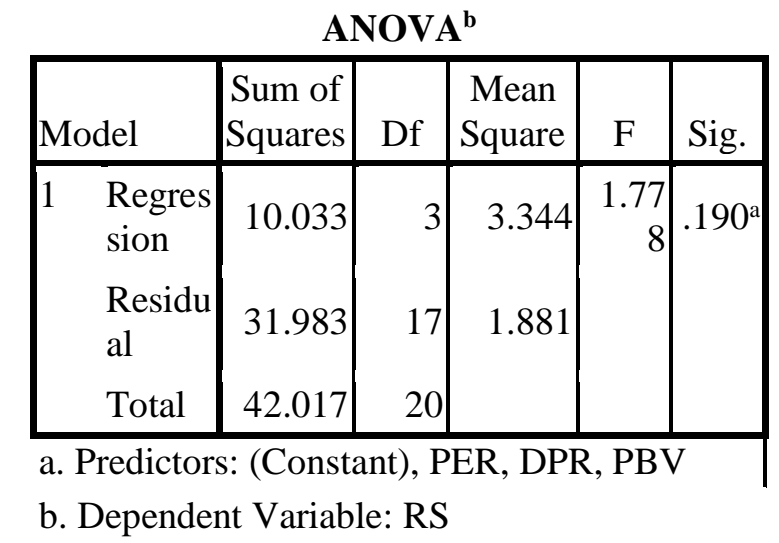

Berdasarkan hasil perhitungan pada SPSS diperoleh nilai signifikan adalah 0,190. Hal ini menunjukkan bahwa nilai signifikan uji $\mathrm{F}$ variabel dividen payout ratio (DPR), price to book value ratio (PBV), dan price to earning ratio (PER) > 0,05 yang berarti $\mathrm{H}_{0}$ diterima dan $\mathrm{H}_{\mathrm{a}}$ ditolak. Hasil dari pengujian simultan ini adalah dividen payout ratio (DPR), price to book value ratio (PBV), dan price to earning ratio (PER) tidak berpengaruh signifikan terhadap return saham .

\section{KESIMPULAN DAN SARAN}

\section{Kesimpulan}

Berdasarkan hasil pengujian hipotesis yang telah dilakukan untuk mengetahui pengaruh dividen payout ratio, price to book value ratio, dan price to earning ratio terhadap return saham pada perusahaan asuransi yang terdaftar di Bursa Efek Indonesia periode 2015 - 2017, maka kesimpulan yang dapat diambil dalam penelitian ini adalah sebagai berikut :

1. Dari analisis data secara parsial diperoleh hasil bahwa variabel dividen payout ratio, memiliki nilai t sebesar 2,249 dengan nilai sig. sebesar 0,038 . Nilai signifikan lebih kecil dari tingkat signifikan yang ditentukan $(0,038 \leq 0,05)$. Jadi hipotesis yang menyatakan bahwa dividen payout ratio berpengaruh signifikan terhadap return saham pada perusahaan asuransi yang terdaftar di Bursa Efek Indonesia.

2. Dari analisis data secara parsial diperoleh hasil bahwa variabel price to book value ratio, memiliki nilai t sebesar 1.540 dengan nilai sig. sebesar 0,142 . Nilai signifikan lebih besar dari tingkat signifikan yang ditentukan $(0,142>$ $0,05)$. Jadi hipotesis yang menyatakan bahwa price to book value ratio tidak berpengaruh signifikan terhadap return saham pada perusahaan asuransi yang terdaftar di Bursa Efek Indonesia.

3. Dari analisis data secara parsial diperoleh hasil bahwa variabel price to earning ratio, memiliki nilai t sebesar -1.378 dengan nilai sig. sebesar 0,186. Nilai signifikan lebih besar dari tingkat signifikan yang ditentukan $(0,186>$ 0,05). Jadi hipotesis yang menyatakan bahwa price to earning ratio tidak 
berpengaruh signifikan terhadap return saham pada perusahaan asuransi yang terdaftar di Bursa Efek Indonesia.

4. Dari analisis data secara simultan diperoleh hasil bahwa variabel dividen payout ratio, price to book value ratio, dan price to earning ratio tidak berpengaruh signifikan terhadap return saham. hal ini dilihat dari nilai $f$ sebesar 1,778 dengan nilai sig. sebesar 0.190. nilai signifikan lebih besar dari $0,05(0,190>0,05)$. Jadi hipotesis yang menyatakan bahwa variabel dividen payout ratio, price to book value ratio, dan price to earning ratio secara simultan tidak berpengaruh terhadap return saham pada perusahaan asuransi yang terdaftar di Bursa Efek Indonesia.

\section{Saran}

Berdasarkan dari hasil penelitian dan kesimpulan di atas, maka saran dalam penelitian ini adalah sebagai berikut:

1. Bagi Calon Investor

Informasi mengenai kemampuan perusahaan dalam menghasilkan laba sangatlah penting bagi para calon investor yang ingin menanamkan modalnya ke suatu perusahaan, tetapi tidak kalah pentingnya jika para calon investor disamping memperhatikan rasio pasar yang berhubungan dengan laba seperti yang digunakan dalam penelitian ini yaitu dividen payout ratio, price to book value ratio, dan price to earning ratio juga harus memperhatikan kondisi keuangan perusahaan karena laba yang tinggi belum tentu perusahaan akan membagikan dividen karena bila kas perusahaan tidak mencukupi untuk membayarkan dividen maka perusahaan akan cenderung menahan laba tersebut guna untuk berinvestasi di masa yang akan datang.

2. Bagi Pihak Perusahaan

Memberikan sinyal positif kepada para pemegang saham merupakan salah satu tujuan utama perusahaan guna mengembangkan usahanya melalui modal yang diinvestasikan kepada perusahaan. Kewajiban perusahaan diharapkan nantinya dapat mengembalikan modal tersebut kepada para pemegang saham berupa dividen, sehingga disamping perusahaan mampu menghasilkan laba yang tinggi dari aktivitas operasi, hal tersebut juga harus diimbangi dengan kondisi kas perusahaan yang likuid supaya dapat memenuhi harapan para pemegang saham dalam hal pembayaran dividen.

3. Bagi Penelitian Selanjutnya

Penelitian ini masih banyak keterbatasan dan penelitian selanjutnya dapat menambah atau mengganti variabel independen yang tidak ikuti diteliti seperti earning per share dan net profit margin, sehingga dalam penelitian selanjutnya melengkapi keterbatasan yang ada dalam penelitian ini tersebut dan mampu menjelaskan variabel yang mungkin memiliki pengaruh lebih besar terhadap return saham. 
Jurnal Cendekia Akuntansi Vol. 1 No. 1

\section{DAFTAR PUSTAKA}

Ariani, Mufty. 2017. Pengaruh Dividen Payout Ratio, Price to Book Value Ratio, dan Earning Per Share terhadap Return Saham. E-Journal S1 Ak Universitas Pendidikan Ganesha Jurusan Akuntansi. Vol 2 No 1.

Brigham, Eugene F, and Joel, Houston. 2009. Dasa-Dasar Manajemen Keuangan. Jakarta : Selemba Empat.

Carlo, Michael Aldo. 2014. Pengaruh Return on Equity, Dividen Payout Ratio, dan Price to Earning Ratio pada Return Saham. E-jurnal Akuntansi Universitas Udayana. Vol 7 No 1.

Darmadji \& Fakhruddin. 2012. Pasar Modal Indonesia. Jakarta : Selemba Empat.

Fahmi, Irham. 2015. Pengantar Teori Portofolio \& Analisis Investasi Teori. Bandung : Alfabeta.

Ghozali, Imam. 2011. Aplikasi Analisis Multivariate dengan Program IBM SPSS. Semarang : Badan Penerbitan Universitas Diponegoro.

Hartono, Jogiyanto. 2009. Teori Portofolio dan Analisis Investasi. Yogyakarta : BEFE.

Novitasari, Andriani. 2015. Pengaruh Price Earning Ratio dan Price to Book Value Ratio terhadap Harga Saham. http://ujurnal.mercubuanayogya.ac.id. Vol 1 no 1.

Prastowo, Dwi. 2011. Analisis Laporan Keuangan. Yogyakarta : Sekolah Tinggi Ilmu Manajemen YKPN.

Sugiyono. 2012. Metode Penelitian Kuantitatif, Kualitatif dan Komboinasi. Bandung : Alfabeta.

Sutrisno. 2008. Manajemen Keuangan Teori Konsep dan Aplikasi. Yogyakarta : EKONISIA.

Tandelin, Eduardus. 2010. Analisis Investasi dan Manajemen Portofolio. Edisi Pertama. Yogyakarta : Kasinius.

Tryfino. 2009. Cara Cerdas Berinvestasi Saham. Jakarta : Trasmedia Pustaka.

Wuldari, Nurul. 2016. Pengaruh Earning Ratio dan Earning Per Share terhadap

Return Saham. Jurnal Ekonomi Manajemen. Vol 2. No 1. 